\title{
The Formation of Students' National Self-Awareness in EFL Class
}

\author{
Iskander E. Yarmakeev $^{1} \&$ Tatiana S. Pimenova ${ }^{1}$ \\ ${ }^{1}$ Institute of Philology and Intercultural Communication, Kazan Federal University, Kazan, Russian Federation \\ Correspondence: Tatiana S. Pimenova, Institute of Philology and Intercultural Communication, Kazan Federal \\ University, Kazan, Vosstaniya Str. 8-53, Russian Federation. Tel: 789-178-644-846. E-mail: \\ pimenova_ts@mail.ru
}

$\begin{array}{ll}\text { Received: August 8,2014 } & \text { Accepted: October 20, } 2014 \quad \text { Online Published: November 19, } 2014 \\ \text { doi:10.5539/elt.v7n12p26 } & \text { URL: http://dx.doi.org/10.5539/elt.v7n12p26 }\end{array}$

\begin{abstract}
In the epoch of globalization it is urgently important to draw attention to the problem of the formation of national self-awareness of school students. Numerous researches in the Russian Federation show that there is a tendency of cultural level decreasing, according to which a great many school students are not aware not only of the world's cultural heritage, but have a vague idea of their own (national) culture. The authors examine the role of foreign languages learning in the formation of national self-awareness of students in High schools. Language, as it is, reflects the culture and history of the nation. Therefore it can be declared a unique source in the process of national self-awareness formation of school students. The cross-cultural approach and the cross-cultural comparative approach in teaching EFL let both, teachers and students, consider human problems from the standpoint of two or more cultures that contribute to the comparative-contrastive analysis of native culture phenomena and compare the native culture with the culture of the target language. Drawing on literature of teaching and learning EFL, multicultural studies, as well as personal international teaching and learning experience, the authors examine the teaching and learning techniques focused on these approaches and present the authentic model of the formation of students' national self-awareness based on the integration of teaching the language and local lore in EFL classes. The paper discusses issues and practices of the studied model and offers general recommendations for High schools faculty.
\end{abstract}

Keywords: interpersonal relations culture, national integrity, national self-awareness, self-esteem raising

\section{Introduction}

Researchers in education and language teaching agree on the point that learning foreign languages is based on the cross-cultural approach and the cross-cultural comparative approach (Vereshchagin \& Kostomarov, 1990; Kharisov, Shaikhutdinova, \& Kharisova, 1995; Elizarova, 2005; Halskova \& Gez, 2005; Evdokimova, 2007; Markova, 2007; Khabutdinova \& Larisa, 2013). In our understanding, comparing and finding similar features in two cultures, i.e. doing some simple cognitive operations, consolidate both national awareness and self-awareness of learners. Students learn to see the world through the eyes of different people, taking into consideration the fact that another person might perceive and estimate the same events quite differently. Tolerance to tastes, habits, viewpoints of others helps students find a common language with the representatives of other cultures.

At present, the ways of the further development of Russia are being discussed. In this context, all the efforts to reform the economic and political system of the country might be not very successful if they neglect "a human factor", that is, if they don't actualize spiritual and moral values in people's awareness that should contribute to the formation of national integrity. In terms of ethnic diversity of the country, peculiarities of social life of the population and specific features of the Russian mentality, the problem of the national self-awareness formation is of a special significance for Russia.

National self-awareness is a factor that binds the nation as a whole spiritual and socio-cultural community. Forming national self-awareness of a personality, we form and develop the nation, making it united and cohesive. National self-awareness forms not only an abiding citizen but a person with an active life position and a good sense of his civic duty, and raises his self-esteem. It cultivates deep respect for national symbols, the heroic past of the country, its culture, love for the native language and nature, and promotes the unity of all citizens regardless of their ethnic origins, political or religious beliefs. National self-awareness is an integrative quality of 
a personality that combines inner freedom and respect for state power, love to homeland and the quest for peace, a sense of dignity and abidance, and an ability to manifest interpersonal relations culture.

It has become a necessity to show that the central role in the formation of national self-awareness of students can be played by the school subject EFL because the communicative orientation of the subject predetermines its openness to studying foreign customs and traditions, history and culture that allows classroom teachers to breed a personality with high moral qualities and a wide world outlook, which is crucial for national self-awareness formation.

\section{Theoretical Framework and Literature Review}

\subsection{Nature of National Self-Awareness}

Until the mid-20 century it was believed that such concepts as 'nation', 'ethnos' would lose their importance in people's lives due to the modernization of the civil society. However, it turned out that their role in social and political processes was even strengthened.

It is close to impossible to understand what national self-awareness is without studying its nature. Sanzharevsky (2010) defines "national self-awareness" as a set of standpoints and assessments that an individual possesses to open unique features of his motherland, its past and its development prospects, to define his national identity, and realize his belonging to his national-ethnic community.

Most Russian (Uledev, 1985; Bromley, 1987, 1988; Drobizheva, 1989, 2002, 2003; Boronoeva, 2000; Tursunov, 2002; Gvozdeva, 2006; Krupnik, 2006; Yarmakeev, 2008) and foreign (Jangildin, 1971, 1988; Dashdamirov, 1976, 1983, 2001, 2007; Vyrost, 1989; Olshansky, 2001; Smith, 2004) scientists consider cognitive, moral and behavioral components to be basic structural components of national self-awareness. All the three components aim at the formation of the ethnic stereotype with ethnic and cultural needs: language, religion, traditions, history and culture. The role of each of them in the formation of national self-awareness of an individual is extremely high.

The problem of the formation of national self-awareness was the subject of a special study of the representatives of many sciences. Milyukov (1925), a historian, a publicist and a politician, regarded this concept as collective consciousness, every member identifying himself finding similarities and differences with others. The author pointed out that language plays the key role in the formation of national self-awareness.

Berdyaev (1908), a political philosopher and a prominent thinker, advocated the theory of national self-awareness formation on the basis of the realization of the religious-moral ideal. According to the author, history is the core of national self-awareness.

Frank (1996), a philosopher and a religious thinker considered national self-awareness to be a universal human category. The author argued that cultural values and life experience are the most important factors that influence the process of national self-awareness formation.

The above mentioned studies have demonstrated that national self-awareness can be regarded a benchmark for characterizing a nation as a community, and an individual as a member of this community. However, literature review on Pedagogy provided evidence that the problem of the formation of national self-awareness has not been thoroughly studied although many educators recognize its importance (Kharisov, Shaikhutdinova \& Kharisova, 1995; Podlasie, 2001; Kharlamov, 2004; Selivanov, 2005). In this paper the authors made an attempt to meet the challenge and explore the problem of the formation of national self-awareness in EFL classes.

\subsection{Formation and Functioning of National Self-Awareness}

\subsubsection{Conditions for the Formation and Development of National Self-Awareness of Learners}

Research has conclusively shown that for the formation and development of national self-awareness of a personality the following conditions should be observed:

1) National environment (language, religion, household items, traditions, geographical features of the living place);

2) National education (culture, literature, the literary language of the nation, history);

3) International communication (Gvozdeva, 2006).

It is believed that the higher national self-awareness of an individual is, the more respectful his attitude to the culture and traditions of other nations becomes; the more respectful the individual's attitude to the culture and traditions of other nations becomes, the more responsible and productive international communication of his can be. 
Vyrost (1989) found that the formation and development of national self-awareness depends on the solution of specific tasks, the main of which are:

- developing and maintaining an inborn feeling of love for homeland in an individual;

- formatting an individual's world outlook;

- providing an individual with a free choice of views, political convictions and beliefs;

- forming an individual's active life-position.

\subsubsection{Interconnection and Interpenetration of Cultures}

The greatest heritage of mankind is an opportunity to communicate with each other. However, the expansion of intercultural interaction may lead either to cooperation or to misunderstanding. This situation poses a challenge to modern education and sets new goals:

- introduction of a personality in the world of human culture;

- upbringing of readiness of a personality for cooperation;

- educating of tolerance and respect for other cultures (Bibler, 1989; Leontovich, 2005; Markova, 2005; Sadokhin, 2005; Mukhametshina \& Galimullina, 2014).

These goals can be successfully achieved in EFL classes since foreign languages learning involves the acquisition of intercultural competence, which means the high level of the foreign language communicative competence plus the familiarization with the culture of the country of the studied language and the mentality of people speaking in this language (Ter-Minasova, 2000; Elizarova, 2005). Formanovskaya (2003) emphasized the importance of learning the "image" of the world of speakers so that the representatives of another culture could not be psychologically "strangers" for learners.

\subsubsection{Intercultural Communication}

Some authors explain the phenomenon of intercultural communication as an adequate mutual understanding of participants of communication belonging to different national cultures (Vereshchagin \& Kostomarov, 1990). The fullest definition of intercultural communication was formulated by Khaleeva (2000): "Intercultural communication is a set of specific processes of interaction between people belonging to different cultures and speaking different languages ... and who are aware of the fact that each of them is 'foreign' and each perceives 'foreignness' of his partner."

Intercultural communication can be done either at the group level or at the individual level. At both levels the main subject of intercultural communication is a person. The behavior of each person is determined by the values and norms of the very culture in which he is included. Consequently, during the direct communication representatives of different cultures face the challenge of overcoming both language differences and differences of the socio-cultural and ethnic character. In the process of intercultural communication each person simultaneously solves two major problems - to preserve his own cultural identity and to engage in a foreign culture.

\section{Methods and Techniques}

\subsection{Research Sites}

The research sites selected for this study were Kazan High school \# 1 and Kazan Gymnasium \# 122.

Kazan High school \# 1 was founded in 1958. The number of students is 550. Most students are from two cultural and linguistic backgrounds: Tatar and Russian. The main goal of school activity is creating a comfortable space for self-realization of each participant of the educational process.

Kazan High school \# 122 was founded in 1958. In 2001, it got the status of Gymnasium \# 122. The number of students is 1200 . Gymnasium \# 122 is ranked among 100 best schools of Russia. The priority direction in work of the gymnasium is the formation of the intellectual, moral and creative personality, freely adaptable in modern society.

Both school educational institutions cooperate with the Institute of Philology and Intercultural Communication of Kazan Federal University.

\subsection{Participants' Backgrounds}

480 school students volunteered to participate in this study. Participants were asked to indicate their grade, gender, ethnicity and the languages spoken. The number of the participants comprised $280(58 \%)$ students of the 
$10^{\text {th }}$ grade and $200(42 \%)$ students of the $11^{\text {th }}$ grade, $380(79 \%)$ females and $100(21 \%)$ males. $210(43,7 \%)$ indicated that they were Russians, $205(42,7 \%)$ indicated that they were Tatars, $62(12,9 \%)$ indicated that they were Jew, $3(0,7 \%)$ indicated that they were the representatives of minority ethnic groups. All students started to learn English as a first foreign language in the 2nd grade. 321 participants indicated that they were also learning a second foreign language.

The goal of gathering these data was to choose the appropriate materials for conducting this study.

\subsection{Studied Materials}

The formation of national self-awareness in EFL class can be realized in two directions: first - the content of the training material, the second - training technologies.

The training material included texts for reading comprehension. By using the texts for reading, the teacher reveals to his students the culture of their country and the target language country as a system of spiritual and material values accumulated by society in all the spheres, from everyday life to philosophy. In doing this, he orients students to the extraction, interpretation, evaluation and transfer of information. The process of reading is an action with the text destined to solve the communicative problem and implement cognitive, regulatory and value-oriented functions of mediated communication. Reading texts that include local lore can play the major role in the formation of students' national self-awareness. Language is storage of culture of ethnos; the experience of the people, their moral and ethical, socio-cultural and educational ideals is accumulated in the language. The appeal to local lore approaches communication in a foreign-language to learners' personal experience and allows them to manipulate those facts and data which they face in everyday life (Toplenkina, 2007; Evdokimova, 2007).

In this research texts for reading were taken from the book by A.A. Rorlikh "The Volga Tatars. A Profile in National Resilience" (Rorlikh, 2000) and short encyclopedic articles about the outstanding people of the Republic of Tatarstan (see Appendices A-C for complete proofs).

The second direction of national self-awareness formation in EFL class assumes the use of both innovative and traditional training technologies, of which the most effective is considered to be the technology that involves dialogue of cultures since it allows to compare cultural traditions of peoples of different countries and to pay a tribute of respect to the religious traditions and the centuries-old rituals which emphasize the value of the person. Such oral-verbal communication tasks like "Complete the sentence: It's impossible to imagine London without Big Ben, Vatican without the Pope. Your city can't be pictured without ..." reach the set goal.

\subsection{Study Instrument and Data Collection Procedures}

The instrument for this study was a set of tests developed by the authors. The tests were preceded by the questionnaire which related to the participants' personal data, including their grade, gender, ethnicity and the languages spoken. Two tests consisted of 10 closed-form questions each designed to check the initial level of local lore knowledge of students (see Appendix D for complete proofs).

There were defined high (80-100\%), average (50-70\%) and low (below 50\%) level of local lore knowledge of students. For this the following scale of measuring the level of local lore knowledge of students was offered: $5 \%$ stood for one correct answer in the test. The results of two tests were summarized.

At a starting point, the diagnostics in the form of testing the initial level of local lore knowledge of students was carried out. At the control stage the same tests were offered. The comparison of quantitative indices of the control stage and the starting point finished the data collection procedures.

\section{Results}

The results revealed that the usage of local lore in EFL class let students acquire basic knowledge both about their own history and culture and world culture, and provided dialogue of cultures.

The quantitative information in Table 1 gives the evidence to the progress of local lore acquisition by students in EFL class.

Table 1. Evaluation of progress of local lore acquisition

\begin{tabular}{lll}
\hline Grades (\# of Participants) & Starting point & Control stage \\
$10^{\text {th }}$ grade (280) & $108(39 \%)$ & $267(95 \%)$ \\
$11^{\text {th }}$ grade (200) & $102(51 \%)$ & $194(97 \%)$ (Note 1) \\
\hline
\end{tabular}


According to these findings, the authors concluded that the true understanding of foreign culture in the course of learning EFL is possible provided the deep knowledge of the history and culture of students' home country.

\section{Conclusion}

At the present stage of the development of the Russian Federation with the deep integration processes in all spheres of public life, language education acts as a significant medium; it forms (has to form) national self-awareness of students and their ability to be socially mobile in society and to freely enter the information space.

This study showed that classroom teachers in EFL classes have got a unique opportunity to raise the level of national self-awareness of their students, acquainting a younger generation with world culture and the culture and history of their own country implementing the model of the formation of students' national self-awareness based on the integration of teaching the language and local lore in EFL classes.

The approbation of the described model of the formation of students' national self-awareness in EFL class proved itself positively. The authors share an opinion that the formation of students' national self-awareness in EFL class is possible provided regular activities based on the cross-cultural approach.

\section{Acknowledgements}

We would like to express deep appreciation to the principals of Kazan High school \# 1 Denis A. Knyazev and Kazan High school \# 122 Olga A. Tigina for their support in conducting our study in their schools.

\section{References}

Berdyaev, N. A. (1989). About Russian national awareness. Black Anarchy. Top Secret, 3, 14-15. http://krotov.info/library/02_b/berdyaev/19081207.html

Bibler, V. S. (1989). Culture. Dialogue of cultures. Philosophical Issues, 6, 31-42.

Boronoeva, A. O. (2000). Basics of sociology and political science. Educational manual. Moscow, M: Gardariki.

Bromley, Y. V. (1987). Ethnosocial processes: Theory, history and modernity. Moscow, M: Nauka.

Bromley, Y. V. (1988). National processes in the USSR: In search of new approaches. Moscow, M: Nauka.

Dashdamirov, A. F. (1976). Nation and identity. Baku.

Dashdamirov, A. F. (1983). The Methodology of research of the national psychological problems. Soviet Ethnography, 2, 62-74.

Dashdamirov, A. F. (2001). National idea and ethnicity. Baku: ELM.

Dashdamirov, A. F. (2007). About some features of modern ethno-national policy. The National Issues and Federal Relations, 6-23.

Drobizheva, L. M. (1989). National identity: Basic socio-cultural incentives for its development. Soviet Ethnography, 5, 3-16.

Drobizheva, L. M. (2002). Social inequality of ethnic groups and problems of integration in the Russian Federation. Moscow, M: Academia.

Drobizheva, L. M. (2003). Social problems of ethnic relations in post-Soviet Russia. Moscow, M: Institute of Sociology, RAS.

Elizarova, G. V. (2005). Culture and foreign language training: Educational manual for university students. St. Petersburg, SPb: KARO.

Evdokimova, M. I. (2007). Educational potential of students in EFL class. Foreign Languages at School, 4, 7-9.

Formanovskaya, N. I. (2003). Culture of communication and speech etiquette. Foreign Languages at School, 5 , 22-27.

Frank, S. L. (1996). Russian outlook. St. Petersburg, SPb: Nauka.

Gvozdeva, E. N. (2006). The education of national awareness among the students of pedagogical universities by means of a foreign language (Doctoral dissertation). Available from the Russian State Library: Full Text (РГБ ОД, 61:07-13/607).

Halskova, N. D., \& Gez, N. I. (2005). Theory of teaching foreign languages: Didactics and methodology. Moscow, M: Academia.

Jangildin, N. D. (1971). The nature of national psychology. Alma-Ata. 
Jangildin, N. D. (1988). The unity of the international and national psychology of the Soviet people. Alma-Ata.

Khabutdinova, M. M., \& Larisa Bayanova. (2013). Norms and Values Characteristics of Students in a Foreign Cultural Environment. Middle-East Journal of Scientific Research, 16(11), 1527-1531. http://dx.doi.org/10.5829/idosi.mejsr.2013.16.11.12041

Khaleeva, I. I. (2000). About gender approaches to the theory of training in languages and cultures. News of the Russian Academy of Education, 1, 11-18.

Kharisov, F. F., Shaikhutdinova, V. H., \& Kharisova, L. A. (1995). Interrelation of national cultures in teaching foreign languages. Methodical tutorial. Kazan, K: Kazan Federal University.

Kharlamov, I. F. (2004). Pedagogy. Educational manual (4th ed.). Moscow, M: Gardariki.

Krupnik, E. P. (2006). National consciousness. Introduction to the problem. Monograph. Moscow, M: Moscow psycho-social institute.

Leontovich, O. A. (2005). The theory of cross-cultural communication in Russia: State and prospects. The Theory of Communication and Applied Communication. Bulletin of Russian Communication Association, 1, 63-67.

Markova, N. G. (2005). Formation of cross-cultural competence at students in educational process. In I. E. Yarmakeev (Ed.), Educational potential of arts education. Implementation of educational potential of the humanitarian education in the conditions of Russia's accession to the Bologna process: Proceedings of the III Conference for High School Faculty, Book 1 (pp. 111-114). Kazan, Tatarstan, Russian Federation, Tatar State University of Humanities and Education.

Markova, N. G. (2007). On language and culture interaction in the modern world. In V. F. Gabdulkhakov (Ed.), Russian as an official language in the Republic of Tatarstan: Proceedings of the 2007 Conference for High School Faculty in the Republic of Tatarstan (pp. 144-149). Kazan, Tatarstan, Russian Federation: Tatar State University of Humanities and Education.

Milyukov, P. N. (1925). Ethnic questions (the origin of nationalities and the national question in Russia). Berlin.

Mukhametshina, R. F., \& Galimullina, A. F. (2014). Inculcation of Bimental Personality in Context of Cultural Dialogue (As Exemplified by Tatarstan Schools). Middle-East Journal of Scientific Research, 20(12), 2135-2138. http://dx.doi.org/10.5829/idosi.mejsr.2014.20.12.21108

Olshansky, D. V. (2001). Fundamentals of political psychology. Educational manual for higher education institutions. Ekaterinburg, E: Business Book.

Podlasie, I. P. (2001). Pedagogy: New course. Textbook for students of higher educational institutions. Moscow, M: Vlados.

Rorlikh, A. A. (2000). The Volga Tatars. A Profile in National Resilience. Moscow, M: Insan.

Sadokhin, A. P. (2005). Introduction to the theory of cross-cultural communication. Moscow, M: Higher School.

Sanzharevsky, I. I. (2010). Political science: Reference Dictionary (6th ed.). Tambov, T: National Encyclopedic Service.

Selivanov, V. S. (2005). Fundamentals of general pedagogy: Theory and methods of education. Manual for students of higher educational institutions (4th ed.). Moscow, M: Academia.

Smith, E. D. (2004). Nationalism and modernism: Critical review of modern theories of nations and nationalism. Moscow, M: Praxis.

Ter-Minasova, S. G. (2000). Language and cross-cultural communication. Moscow, M: Slovo.

Toplenkina, I. P. (2007). Regional component at lessons of a foreign language. Foreign Languages at School, 3, 51-53.

Tursunov, F. A. (2002). Socio-cultural features of formation and development of national awareness (on the example of the Tajik people) (Doctoral dissertation). Available from the Russian State Library: Full Text (РГБ ОД, 61 03-9/211-3).

Uledev, A. K. (1985). Social psychology and ideology. Moscow, M: Mysl.

Vereshchagin, Y. M., \& Kostomarov, V. G. (1990). Language and culture: Linguistics in teaching Russian as a foreign language (4th ed.). Moscow, M: Russian Language.

Vyrost, I. S. (1989). National self-awareness: Problems of definition and analysis. Philosophical and Social 
Thoughts, 7, 22-26.

Yarmakeev, I. E. (2008). Spiritual and moral education of a future expert: System formation. Moscow, M: Vlados.

\section{Notes}

Note 1. Figures in parenthesis refer to percentages and have been rounded up to whole numbers.

Note 2. Your project may contain photos, pictures, some historical information, interesting facts, etc. about the famous person.

\section{Appendix A}

\section{An outline for the class activity.}

I. Read the key words: principalities, smooth, tension, campaigns, devastated, hostilities, economic, disrupted, agriculture, economy, plow, virgin, cultivated, barley, wheat.

II. Read the text The Bulgar State and answer the following questions:

1) Why, in your opinion, the Bulgar state and the neighboring Russian principalities were at one and the same time trade partners and enemies, that penetrated each other's lands from time to time?

2) Why was the Bulgar economics, suffering from the conflicts with Russian principalities, still working?

3) Why was The Volga-Kama region suitable for agriculture?

III. Read the text The Bulgar State more carefully. Match the words with their meanings. Write the suitable word near the appropriate meaning:
1) Clash
a) the people living together in one house collectively
2) Hostility
b) a piece of equipment; tool or utensil
3) Disruption
c) a collision or conflict
4) Implement
d) breaking or splitting (something) apart
5) Household
e) enmity or antagonism

The Bulgar State (from the book by A. A. Rorlikh "The Volga Tatars. A Profile in National Resilience")

The relationship of the Bulgar state with the neighboring Russian principalities was neither smooth nor free of tension. In fact, throughout the twelfth and thirteenth centuries, they clashed frequently. The Russian campaigns against the Bulgars unfolded over an entire century, with the most notable ones taking place in 1120, 1160, 1164, 1172, 1183, and 1120 - at which times Russian armies devastated the right bank of the Volga, destroying the city of Oshel. The Bulgars, in turn, penetrated the Russian lands in 1201 and 1219, and it was only the imminent Mongol danger in 1223 that brought the hostilities to an end and led to conclusion of a peace treaty.

Despite tension and frequent clashes, the relationship between the Bulgar State and the Russian principalities was not solely one of hostilities. Trade and commercial ties were as important for the Bulgars as they were for the Russian principalities, and the economic life of the Bulgar state, although disrupted by hostilities, never came to a halt because of them. Agriculture, crafts, cattle breeding, hunting, fishing, and trade represented the backbone of Bulgar economy.

The Volga-Kama region, with its rich black soil, was suitable for the agriculture. The two-field system that was used was particularly suitable for the cultivation of virgin lands. The basic implements were the heavy metal plow (saban) with a single share, which was effective for the virgin, blackearth soils, and the light wooden plow with two iron shapes used for podzol soils.

The climate, more than the soil or agricultural technology, determined the types of crops the Bulgars cultivated. Barley, wheat, and millet seem to have been the traditional crops because most travelers noted their presence in the Volga-Kama region. Ibn-Fadlan commented: 'They met us carrying bread, meat, and millet ... their food consists of millet and horsemeat but they have also wheat and barley in abundance, and every one of them who planted this harvests it for himself. The ruler does not have any right to this, except for the fact that they all pay him every year one sable pelt per household.' 


\section{Appendix B}

\section{An outline for the class activity.}

I. Read the key words: ethnogenetic, hindered, emergence, ethnonym, rehabilitation, challenged, proponents, etymology, contempt, subdued, khan, demise, seminomadic, bequeathed, minorities, assimilation, testimony, bestowed.

II. Read the text The Origins of the Volga Tatars carefully. Are these statements true or false?

1) There are two major groups in the Turkic nationalities living in Russia.

2) Volga Tatars never identified themselves as Muslims.

3) There are a lot of theses on the origin of the ethnonym Tatar.

4) The Mongols and the Mongol Tatars underwent a process of assimilation by the Turkic peoples among whom they lived.

III. Read the text The Origins of the Volga Tatars and solve the crossword:

Across

1) How did the Volga Tatars prefer to identify themselves in the $2^{\text {nd }}$ half of the XIX century?

2) Batu's army was called the Golden ...

3) The surname of one of the enlightened Tatar thinkers.

4) The way of life led by the Turkic khanate in the VI-VII centuries AD.

Down

1) The second major group of the Volga Tatars.

2) The name of the famous Mongol khan, the grandfather of Batu.

3) The Mongolian name for the word council.

4) To capture (synonym).

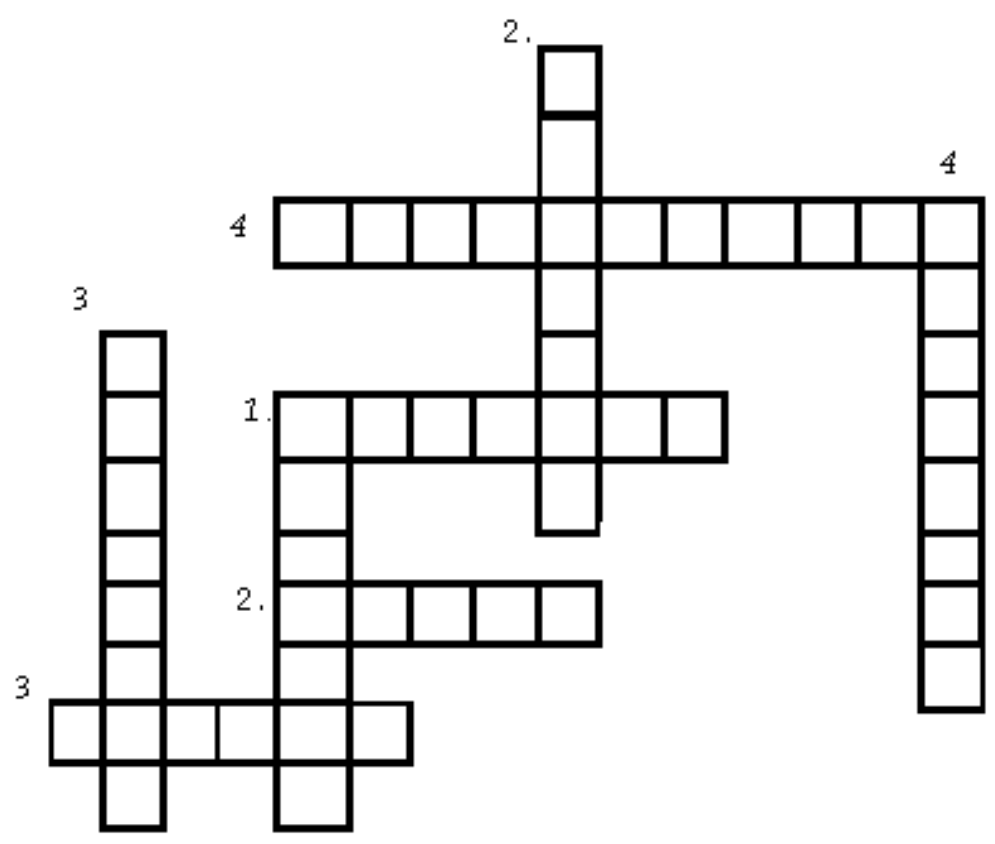

The Origins of the Volga Tatars (from the book by A. A. Rorlikh "The Volga Tatars. A Profile in National Resilience")

The Volga Tatars are the westernmost of all Turkic nationalities living in Russia. Among them, there are two major groups - the Kazan Tatars and the Mishars; although each is characterized by linguistic and ethnogenetic particularities, their differences have not hindered the emergence and development of a common language and 
culture.

The Ethnonym Tatar. As late as the second half of the XIX century, Volga Tatars preferred to identify themselves, and to be identified by others, as Muslims.

At the end of the XIX century, enlightened Tatar thinkers, such as Kayum Nasiri and Shihabeddin Marjani, played a major role in the rehabilitation of the ethnonym Tatar. S.Marjani urged the Kazanis not to be ashamed to call themselves Tatars. He noted that "Some have regarded being a Tatar a shortcoming, hated it, and insisted 'We are not Tatars, we are Muslims' ... If you are not Tatar, Arab, Tajil, Nogay, Chinese, Russian, French ... then who are you?" challenged S.Marjani.

What is the origin of the ethnonym Tatar? Two theses stand out: the Mongol and the Turkic.

Proponents of the first accept the etymology of Tatar as deriving from the Chinese Ta-Tan or Da-Dan (a term of contempt applied to the Mongols by the Chinese) and believe that it refers to one group of Mongol tribes subdued by Ginghis Khan.

The Mongol Tatars lived amidst Turkic tribes that had survived the demise of the seminomadic Turkic khanate of the VI and VII centuries A.D. After their conquest by Ginghis Khan at the beginning of the XIII century (1202-1208), the Mongol Tatars, as well as the Turkic tribes of the southern Siberian plains and Central Asia, were included in the army headed by Ginghis Khan's grandson, Batu. In 1236, Batu, in the company of his sons Chagatai, Ogotai, and Tului, set out to conquer the eastern European lands bequeathed to him at the 1235 kurultai (council). Conquering the lands beyond the Ural mountains and the Aral and Caspian seas, the Mongols came into contract with the Turkic Kypachaks, who had reached the zenith of their political power in the XI and XII centuries A.D. as rulers of Dasht-i Kypchak, the huge territory between the Irtysh and Danube rivers.

The Mongols and the Mongol Tatars, who were minorities in Batu Khan's army and even smaller minorities among the peoples of the Golden Horde that had emerged after Batu's conquest of the lands beyond the Urals, underwent a process of assimilation by the Turkic peoples among whom they settled. This assimilation was both biological and cultural.

The Turkic thesis, which is not as widely accepted as the Mongol thesis, was advanced by scholars who rely heavily on the Diwan-i Lugat-it-Turk, a dictionary of the Turkic languages complied by Mahmud al-Kashari during the period 1072 to 1074. In this book, Mahmud al-Kashgari mentions that west of the Irtysh river there existed a Tatar branch of the Turkic languages. Ahmet Temir interprets this information as a testimony to the existence of a Turkic people called Tatars long before the Mongol conquest bestowed the name on the peoples of the Golden Horde. Broadening his interpretation of the information provided by the dictionary, Ahmet Temir also suggests that the name could apply independently and equally to two different peoples: the Mongol tribe of Tatars and a Turkic tribe that inhabited a territory west of the Ural mountains.

\section{Appendix C}

\section{Project work.}

Make a project "A Famous Person" that will tell about one personality mentioned in the article "A Walk around Kazan.” (Note 2)

\section{A Walk around Kazan}

In fact, Kazan was involved into two distinct parts: the upper town with the Kremlin, where the Russian gentry, merchants and craftsmen lived, and the lower town, the old Tatar and new Tatar settlements, where Tatar tradesmen, merchants and even peasants lived, the latter cultivated fields that extended to the very edge of the lower town.

The visible border between the upper and lower towns, and in fact between the cultures of the East and West, lay along the Bulak Canal and the chain of Kazan lakes: Near, Middle and Far Kaban. On either side of this watery boundary the city developed its dynamic and distinctive life, leaving an unforgettable impression on its visitors. In the XIX century, Alexander Herzen wrote: 'Kazan is somehow the main focus of the neighboring provinces to the south and east: they receive their education, customs and fashions from it. The significance of Kazan is very great: it is the place where two worlds meet. It has two origins, the West and the East, and you can see them at every cross-roads; here they lived together in amity ... and began to create something quite original.'

Kazan is inseparably linked not only with Alexander Pushkin, Eugene Baratynskiy, Leo Tolstoy, Nicholas Lobachevskiy, Gavril Derjavin, Maxim Gorky and Fyodor Shalyapin, but also with the outstanding representatives of the Tatar culture, such as Kayum Nasyri, Shigabetdin Mardzhani, Gabdulla Tukay, Fatikh Amirkhan, Gayaz Iskhaki and many others. 


\section{Appendix D}

Test 1 (A Sample).

\# Question

1. How tall is the Suyumbika Tower, the most remarkable building of the Kremlin?
Choose the correct answer (only one answer is correct)
A) 58 meters
B) 62 meters
C) 87 meters

2. Who is the author of the well-known Tatar poem Shurale?

\section{A) Kamal}

B) Djalil

C) Tukai
A) 1676
B) 1766
C) 1876

3. When was the Empress Catherine in Kazan?

4. What Russian monarch first visited Kazan?
A) The Empress Catherine
B) The Emperor Peter the Great
C) The Emperor Nicholas the First

5. Who is the annual ballet festival held in Kazan named after?
A) Rudolf Nuriev
B) Feodor Chaliapin
C) Mikhail Baryshnikov

6. On the bank of which Lake is the Tatar Drama Theater located?
A) Kaban Lake
B) Bulak Lake
C) Lebyazhye Lake

7. Who wrote a book $A$ Bee, its Life and the Main Rules of A) Alexander Arbuzov

7. Bee-Farming, that was republished dozens of times?

B) Alexander Duma

C) Alexander Butlerov
8. In what year was Kazan Federal University founded?
A) 1725
B) 1804
C) 1861

9. How many walking streets are there in Kazan?
A) one
B) two
C) three
10. In what year did Kazan celebrate its 1000-th anniversary?
A) 2000
B) 2005
C) 2013

\section{Copyrights}

Copyright for this article is retained by the author(s), with first publication rights granted to the journal.

This is an open-access article distributed under the terms and conditions of the Creative Commons Attribution license (http://creativecommons.org/licenses/by/3.0/). 